\title{
Structural Characterization of Silica Particles Extracted from Grass Stenotaphrum secundatum: Biotransformation via Annelids
}

\author{
A. Espíndola-Gonzalez, ${ }^{1}$ R. Fuentes-Ramirez, ${ }^{1}$ A. L. Martínez-Hernández, ${ }^{2,3}$ \\ V. M. Castaño, ${ }^{2,4}$ and C. Velasco-Santos ${ }^{2,3}$ \\ ${ }^{1}$ Division de Ciencias Naturales y Exactas, Departamento de Ingenieria Quimica, Universidad de Guanajuato, \\ Campus Noria Alta, Guanajuato, GTO 36050, Mexico \\ ${ }^{2}$ Centro de Fisica Aplicada y Tecnologia Avanzada, Universidad Nacional Autonoma de Mexico, \\ Boulevard Juriquilla No. 3001, Queretaro, QRO 76230, Mexico \\ ${ }^{3}$ Division de Estudios de Posgrado e Investigacion, Instituto Tecnologico de Queretaro, \\ Avenida Tecnologico S/N Esq. Gral. Mariano Escobedo, Col. Centro Historico, Queretaro, QRO 76000, Mexico \\ ${ }^{4}$ CIATEQ, Av. El Retablo 150, Queretaro, QRO 76150, Mexico
}

Correspondence should be addressed to C. Velasco-Santos; cylaura@gmail.com

Received 16 October 2013; Revised 22 January 2014; Accepted 12 February 2014; Published 14 April 2014

Academic Editor: Aldo Craievich

Copyright (C) 2014 A. Espíndola-Gonzalez et al. This is an open access article distributed under the Creative Commons Attribution License, which permits unrestricted use, distribution, and reproduction in any medium, provided the original work is properly cited.

\begin{abstract}
This study shows the structural characterization of silica particles extracted from Stenotaphrum secundatum (St. Augustine) grass using an annelid-based biotransformation process. This bioprocess starts when St. Augustine grass is turned into humus by vermicompost, and then goes through calcination and acid treatment to obtain silica particles. To determine the effect of the bioprocess, silica particles without biotransformation were extracted directly from the sample of grass. The characterization of the silica particles was performed using Infrared (FTIR) and Raman spectroscopy, Transmission Electron Microscopy (TEM), X-ray Diffraction (XRD), Dynamic Light Scattering (DLS), and Energy Dispersion Spectroscopy (EDS). Both types of particles showed differences in morphology and size. The particles without biotransformation were essentially amorphous while those obtained via annelids showed specific crystalline phases. The biological relationship between the metabolisms of worms and microorganisms and the organic-mineral matter causes changes to the particles' properties. The results of this study are important because they will allow synthesis of silica in cheaper and more ecofriendly ways.
\end{abstract}

\section{Introduction}

Of all plants, the grasses are the most important to man. All our breadstuffs, corn, wheat, oats, rye, barley, and rice, are grasses. The food, agricultural, and forestry industries produce large volumes of waste annually worldwide as byproducts of use of these grasses, causing a serious disposal problem; however, they constitute a renewable resource from which many useful materials can be derived. In leaves of grasses, silica can constitute 2-5\% dry matter, 10-20 times higher than levels found typically in dicotyledonous plants [1]. Silica is stored primarily as opaline phytoliths in the epidermis [2]. Although all plants rooting in soil contain some $\mathrm{Si}$ in their tissues [3], the content differs greatly between plant species because of differences in Si uptake by the roots. Uptake and translocation occur as monosilicic acid and the deposition form is amorphous silica gel $\mathrm{SiO}_{2} \cdot n \mathrm{H}_{2} \mathrm{O}$ [4]. Accumulation of such high levels of a single mineral element within grasses family suggests that it has a functional significance. Progress in understanding the uptake and accumulation of Si in plants has been led extensively by some authors [5-8]. The opal-like phytoliths (hydrated amorphous silica) occur in the tissue of grasses in a threedimensional distribution in such a way as to suggest that 
silica is being excluded from the cells and deposited as silica gel in the spaces between cells. The silica is transported as $\mathrm{Si}(\mathrm{OH})_{4}$ and then concentrated and gelled as water evaporates from the leaves. Pores in the gel measure between 1 and $10 \mathrm{~nm}$ in diameter and are full of water, making silica completely amorphous [9]. Precipitation and polymerization of the silica, aided by evaporation and water metabolism in the plant's body, lead to the formation of intra- as well as extracellular silica bodies. Intracellularly, silica accumulates in both the cytoplasm and the vacuoles of the plant cells and can be deposited in roots, stem, and leaves. Earlier, our group reported the synthesis of nanoparticles of silica oxide from rice husk, sugar cane bagasse, and coffee husk, by employing vermicompost with annelids (Eisenia foetida) [10]. The characterization of these particles can contribute to the understanding of the natural mechanism of transformation from the amorphous form to nanocrystals oxides in intestines of the worms. This bioprocess can be applied in the use of waste grass to produce specific nanocrystals with potential applications in materials science.

St. Augustine grass (Stenotaphrum secundatum) is native to the coastal regions of the Gulf of Mexico and the Mediterranean. This specimen is widely used as a turf grass in warm, humid, tropical, and subtropical climates where its broad leaf blades produce a tight canopy from rapidly elongating stolons, resulting in a coarse-textured turf [11]. Adaptive and morphological variations in St. Augustine grass are associated with chromosome differences. The most conspicuous differences among ploidy levels are that diploids are lower growing and have narrower, translucent, bright green leaf blades while polyploids have coarser, thicker leaf blades that are blue/green and less saturated in colour [12]. Although commonly found on siliceous and calcareous sands near the sea, St. Augustine grass also grows on a wide range of well to poorly drained soils, from sandy loams to light clays. Silicon accumulation in dry land Gramineae such as St. Augustine grass has been reported to be between 0.5 and $1.5 \%$, while in dicotyledons (i.e., broadleaf plants) it is less than $0.2 \%$. Indeed, the amounts of silicon that plants accumulate from the soil can be much higher than the amounts of any other essential macro- or micronutrients [13].

Vermicompost is the excreta of earthworms, which are capable of improving soil health and nutrient status. Vermiculture is a process by which all types of biodegradable waste, such as farm wastes, kitchen wastes, market wastes, biowastes of agrobased industries, and livestock wastes, are converted while passing through the worm gut to nutrient rich vermicompost. Vermi worms are used here as biological agents to consume those wastes and to deposit excreta in the process called vermicomposting [14]. Vermicomposting is a simple biotechnological process of composting, in which certain species of earthworms are used to enhance the process of waste conversion and produce a better product. Vermicomposting is a mesophilic process that utilizes microorganisms and earthworms that are active at $10^{\circ} \mathrm{C}$ to $32^{\circ} \mathrm{C}$ (not ambient temperature but the temperature within the pile of moist organic material). The process is faster than composting because the material passes through the earthworm gut and a significant but not fully understood transformation takes place, whereby the resulting earthworm casting (worm manure) is rich in microbial activity. Earthworms have been long recognized by farmers as beneficial to soil [15] and, as one of the major soil macrofauna, constitute an important group of secondary decomposers. Earthworms are key biological agents in the degradation of organic wastes [16]. Each earthworm weighs about 0.5 to $0.6 \mathrm{~g}$, eats waste equivalent to its body weight, and produces cast equivalent to about $50 \%$ of the waste it consumes in a day. These worm castings have been analysed for chemical and biological properties. The moisture content of castings ranges between $32 \%$ and $66 \%$ and the $\mathrm{pH}$ is around 7.0. The final product of vermicompost bioprocess is called humus and it could be considered a driving force in the varying nature of terrestrial ecosystems [17]. Humus differs from the nonhumic substances such as carbohydrates (a major fraction of soil carbon), fats, waxes, alkanes, peptides, amino acids, proteins, lipids, and organic acids by the fact that distinct chemical formulae can be written for these nonhumic substances. Most small molecules of nonhumic substances are rapidly degraded by microorganisms within the soil. In contrast, soil humus is slow to decompose (degrade) under natural soil conditions. In combination with soil minerals, soil humus can persist for several hundred years. Some of the most beneficial attributes of humus are associated with its ability to make small, inorganic particles adhere together as loose, friable aggregates. Earthworm activities determine the soils' characteristics and take an active part in energy and nutrient cycling through the selective activation of both mineralization and humification processes [18].

Apparently, in earthworms the mineralization is biologically induced, which is described as a mostly unintentional consequence of metabolic activities in the microbial organism. The nanoparticles produced in this process are an extracellular by-product of the microbial metabolism. The bacteria or other types of microbe secrete organic products attract ions or compounds in their vicinity, which subsequently result in concentration, alteration, immobilization, or depletion of these minerals. This means that the formation of elemental crystals is not directly controlled by the microbe. This can produce random crystallization or a lack of specific crystal morphologies [19]. Minerals formed in this manner also tend to be impure in the crystal lattice and full of inclusions of other minerals and compounds [20]. Some works about biotransformation and the biomineralization process where earthworms are involved have been reported $[21,22]$. In the earthworms intestine there exist a wide range of microorganisms, including bacteria, algae, protozoa, actinomycetes, fungi, and even nematodes, which are found commonly throughout the length of the earthworms gut. The species of microbes in the gut are usually very similar to those in the surrounding soil or organic matter upon which the earthworms feed. Earthworms are dependent upon range of microorganisms in their nutrition and probably fungi are the most important microbes as food. It seems likely that protozoa are also important in their diet but that bacteria and actinomycetes are much less important [23]. Several studies have showed that under certain conditions of pressure and temperature the biomineralization (silicification) can be induced in presence of microorganisms 
and demonstrated that a complex interplay exists between the precipitations of silica, texture, and structures formed [24].

This study shows the structural characterization of silica particles extracted from grass Stenotaphrum secundatum (St. Augustine) using an annelid-based biotransformation process. The aim was to investigate changes in the properties of these particles caused by the bioprocess, and we propose that these biostructures could be used for the synthesis of new materials in a cheap and ecofriendly manner.

\section{Materials and Methods}

The seed of St. Augustine grass (Stenotaphrum secundatum) (Walt.) Kuntze was obtained from a commercial source, planted in a garden, and grown for about 3 months. Once mowed, it was added to the vermicompost. The specimen of annelid used was Eisenia foetida. The environmental conditions ideal for the reproduction and control of these samples were set up: temperature at $20^{\circ} \mathrm{C}$, moisture around $60-85 \%$, aeration conditions, and darkness. The stabilization time was around 1 month and the humus obtained was dried at room temperature. Then, the humus was sieved to a size of approximately $0.5 \mathrm{~mm}$. Next, the sample was calcinated for $19 \mathrm{~h}$ at a temperature of $500^{\circ} \mathrm{C}$ to eliminate the organic matter. Calcinations were carried out in a muffle Lindberg/Eurotherm model 847 with energy consumption of $0.17 \mathrm{kcal} / \mathrm{h} \mathrm{cm}^{3}$, and then the samples were treated with nitric and hydrochloric acids (volume ratio $3: 1$ ). For each gram of sample calcinated, $4 \mathrm{~mL}$ of acid mix was added in order to eliminate impurities. Acid treatment was performed at $40^{\circ} \mathrm{C}$ for $4 \mathrm{~h}$ with constant stirring. Then, the sample was filtrated and washed with distilled water to neutralize it. Solids obtained were dried at room temperature. All reagents employed were provided by Sigma-Aldrich. Silica obtained from St. Augustine grass without the bioprocess was used as a reference. The extraction process to obtain silica without bioprocess is the same described previously using calcination and acid treatment.

Silica powders were characterized to 64 scans by employing a Fourier transform infrared spectrophotometer (FTIR) Bruker Vector 33 with a resolution of $4 \mathrm{~cm}^{-1}$, using $\mathrm{KBr}$ powders. Raman spectroscopy was performed in a Raman Senterra Bruker machine with a 100x microscope objective, laser emitting, at $785 \mathrm{~nm}$ and resolution $0.1 \mathrm{~cm}^{-1}$. Transmission Electron Microscopy (TEM) was performed using a JEOL TEM-1010 transmission electron microscope. Average particle size was determined by Dynamic Light Scattering (DLS) using a Brookhaven model BI200SM with laser He-Ne of $35 \mathrm{~mW}$ model 9167 EB-1 Melles-Griot. Elemental analysis was carried out using energy dispersion spectroscopy (EDS) mean software Oxford Inca X-Sight. EDS is adapted in equipment JEOL JSM-6060 LV Scanning Electron Microscope. Xray Diffraction (XRD) was performed in a diffractometer Rigaku, Model MiniFlex, with a wavelength from $1.54 \AA$ corresponding to ka cupper radiations. Crystalline structures present in the samples were analysed with Materials Data Jade software of MDI Materials Data.

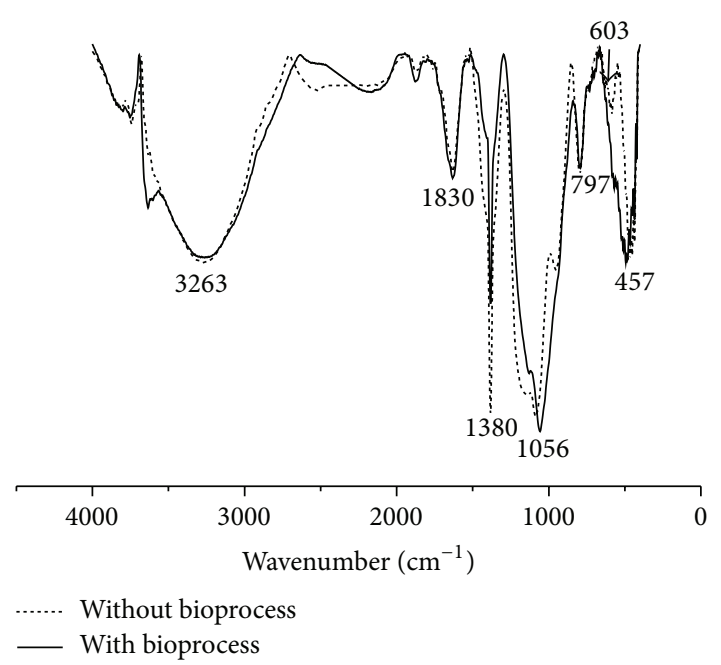

FIGURE 1: IR spectra of silica particles obtained for annelids bioprocess and without bioprocess.

\section{Results and Discussion}

3.1. Infrared Spectroscopy (FT-IR). Figure 1 presents FT-IR spectra of both samples of silica (with and without bioprocess). Every spectrum shows a wide peak at $3263 \mathrm{~cm}^{-1}$ ascribable to the $\mathrm{O}-\mathrm{H}$ stretching mode of water molecules as well as a peak assigned to the water hydroxyl deformation vibration at $1630 \mathrm{~cm}^{-1}$ — these bands correspond to adsorbed water that minerals contain physically $[25,26]$. At $1379 \mathrm{~cm}^{-1}$, there exists a band associated with the mineral phases of carbonates (i.e., calcite, dolomite, and aragonite); these compounds are common in soils and are generally produced by a biomineralization process. Although the carbonates can be thermally unstable, their stability increases with the type of cation associated and so can prevail even in the treatment conditions of the sample [27]. This band is less intense in the sample with bioprocess due in great part to the fact that this mineral source can be necessary in the metabolism of the earthworms. A band corresponding to $\mathrm{Si}-\mathrm{O}$ asymmetrical stretching vibration was localized at $1056 \mathrm{~cm}^{-1}$ [28], and this band is very similar in both samples with and without bioprocess. Another band localized at $797 \mathrm{~cm}^{-1}(\mathrm{Si}-\mathrm{O})$ is related to the presence of quartz in the sample [29]. In the region between 400 and $600 \mathrm{~cm}^{-1}$, the sample with bioprocess shows a peak at $457 \mathrm{~cm}^{-1}$ corresponding to $\mathrm{Si}-\mathrm{O}-\mathrm{Si}$ bending vibration [30]; without bioprocess the sample exhibits a peak in $603 \mathrm{~cm}^{-1}$; this can be assigned to a compound silicate that contains magnesium [31]. In the bioprocess is a band not observed; however this can overlap with the band localized in $457 \mathrm{~cm}^{-1}$. The results of FTIR show the existence of bands where silica prevails, but the differences in these bands (with and without bioprocess) can aid in explaining the mechanism of the bioprocess in the earthworms.

3.2. Raman Spectroscopy. The FT-Raman spectrum of the sample with and without bioprocess is shown in Figures 2(a) and 2(b). FT-Raman bands were well defined only in the 


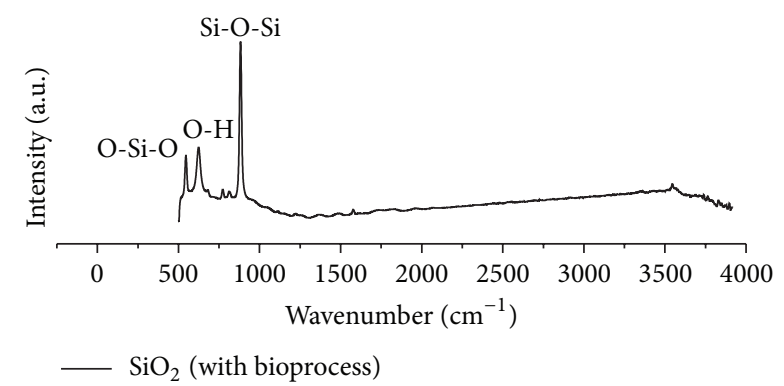

(a)

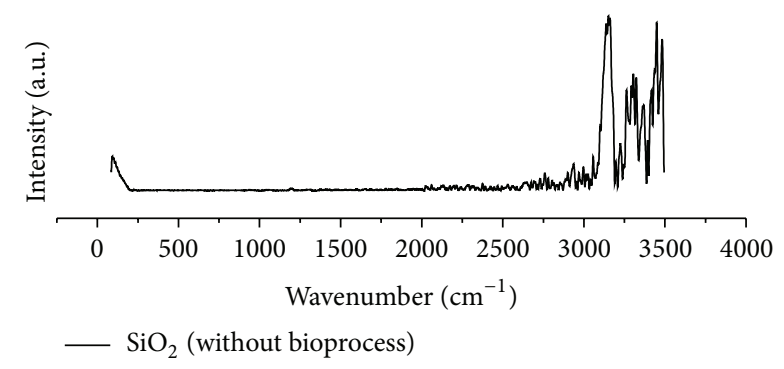

(b)

FIGURE 2: FT-Raman spectra of silica particles obtained for annelids bioprocess (a) and without bioprocess (b).

sample of silica with bioprocess (Figure 2(a)). These bands are localized at $122 \mathrm{~cm}^{-1}, 210 \mathrm{~cm}^{-1}$, and $468 \mathrm{~cm}^{-1}$. The first band at $122 \mathrm{~cm}^{-1}$ corresponds to an $\mathrm{O}-\mathrm{Si}-\mathrm{O}$ symmetric bend; the second band localized at $210 \mathrm{~cm}^{-1}$ is assigned to stretch vibration modes of $\mathrm{O}-\mathrm{H}$ group, while the intense band localized at $468 \mathrm{~cm}^{-1}$ is associated with the $\mathrm{Si}-\mathrm{O}-\mathrm{Si}$ stretching vibration. This last band has a stronger intensity and belongs to the polymorph of silica $\alpha$-quartz typically found at $465 \mathrm{~cm}^{-1}$ [32]. FT-Raman results confirm the presence of silica and suggest that in samples with bioprocess a crystalline arrangement is present in contrast with the samples without bioprocess, thus confirming that microorganisms contribute to the molecular ordering.

\subsection{Transmission Electron Microscopy (TEM). TEM images} of silica sample with bioprocess are shown in Figures 3(a)3(c). In this case, the particles extracted using the annelid bioprocess have a morphology similar to spherical, they are grouped in clusters, and have a nanometric size. TEM images of silica sample without bioprocess are shown in Figures 3(d)-3(f). In this figure, particles were not identified nor had their morphology defined, but clusters and agglomerates were observed and their size apparently was bigger than particles without bioprocess. The results showed a difference in the morphology, dispersion, and size between the samples. Without the bioprocess, the particles have a tendency to be amorphous, while, with the bioprocess, these particles display more order and these differences are attributed to the vermicomposting bioprocess. Microorganisms play important role in this process due to the activity of classification and purification of the matter employed in their metabolic process.
3.4. X-Ray Diffraction (XRD). XRD diffractograms of the sample of silica with the bioprocess are given in Figure 4(a). Figure 4(a) shows characteristic peaks related to hexagonal quartz (Figure 4(a), peak 1) - this quartz has been identified earlier as belonging to a polymorph of silica. Also hexagonal tridymite (primitive) (Figure 4(a), peak 2) and triclinic albite (Figure 4(a), peak 3) polymorphs were identified. XRD diffractograms of the sample without the bioprocess are given in Figure 4(b). Figure 4(b) shows that the particles have a structure essentially amorphous and only two peaks related to hexagonal quartz polymorphs can be detected slightly (Figure 4(b), peaks 1 ). These results confirm that the bioprocess plays an important role in the transformation of the particles toward a crystalline structure. In this type of grass, polymorphs of silicates prevail, although, as can be observed in EDS, mineral elements exist that can produce other crystalline structures.

3.5. Dynamic Light Scattering (DLS). The mean diameter of particle estimated by DLS showed that with the bioprocess the particles achieved 530 nanometres while without the bioprocess the mean diameter was 1.6 micrometres. These results show that with the bioprocess the size of silica particles is smaller than the size of those without bioprocess. The mineral portion (phytoliths) in grass is generally microscopic; however, the metabolic activity of microorganisms inside the intestine of earthworms causes an important size reduction. This analysis shows that the size of particle can be affected by the trend of the samples to form agglomerates; this can be better observed in the sample without bioprocess.

3.6. Energy Dispersion Spectroscopy (EDS). Table 1 summarizes the results obtained using energy dispersion spectroscopy. A significant amount of silicon and oxygen weight percentage was observed in the samples: with bioprocess: $54.01 \% \mathrm{O}$ and $30.69 \% \mathrm{Si}$ and without bioprocess: $56.23 \% \mathrm{O}$ and $35.44 \% \mathrm{Si}$. Table 1 shows other elements in lower proportion related to the biomineralization process and some were detected using the technique of X-ray Diffraction (Figure 4). Elements such as magnesium, aluminium, and iron increased their proportion when the bioprocess is used. The relationship of oxygen and silicon in the samples is similar, although the oxygen is slightly lower in the sample with the bioprocess due to this element being an important source in the metabolic process of earthworms and microorganisms. EDS showed the mineral elements in the samples with and without the bioprocess, and it is important to remark that elements such as sodium and calcium only are shown in the sample without the bioprocess, while in the bioprocess are elements that are an important source in the nutritional process of earthworms and can be used by the microorganisms.

\section{Conclusions}

The effect produced by the annelid bioprocess on the properties of silica particles obtained from St. Augustine grass was determined. The characterization of these particles was performed with FTIR, Raman spectroscopy, TEM, XDR, 


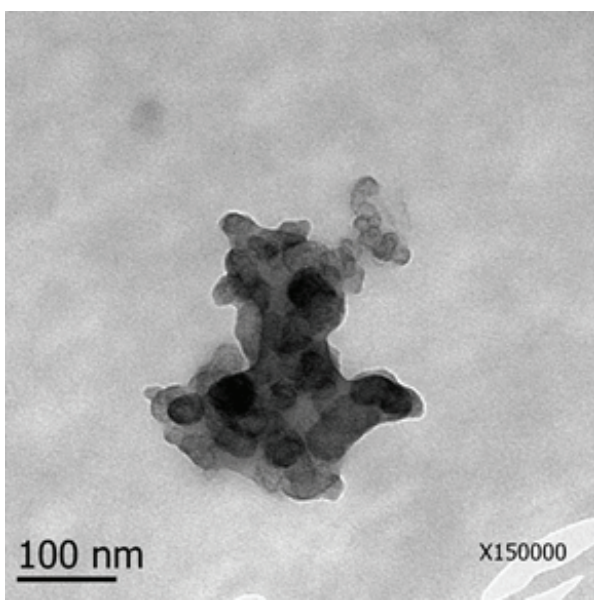

(a)

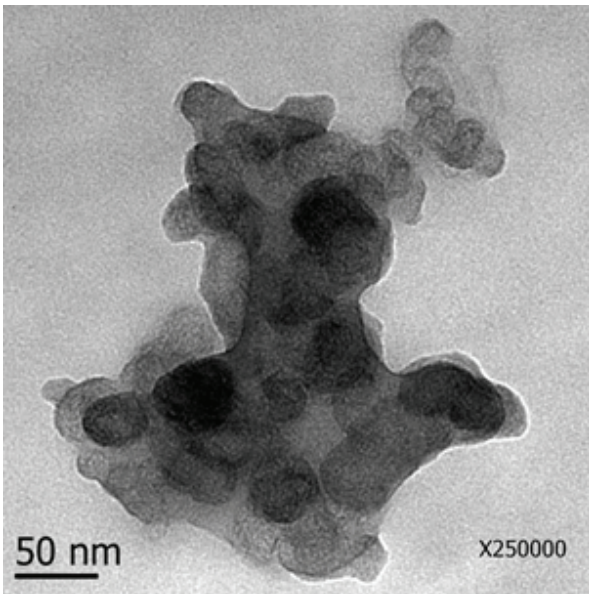

(c)

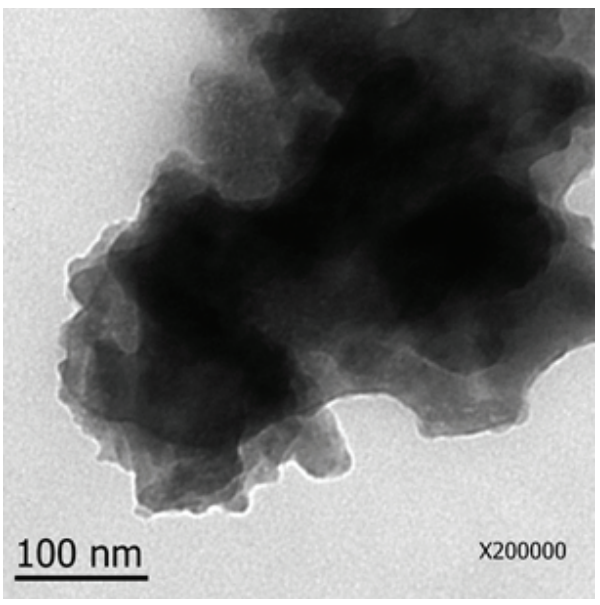

(e)

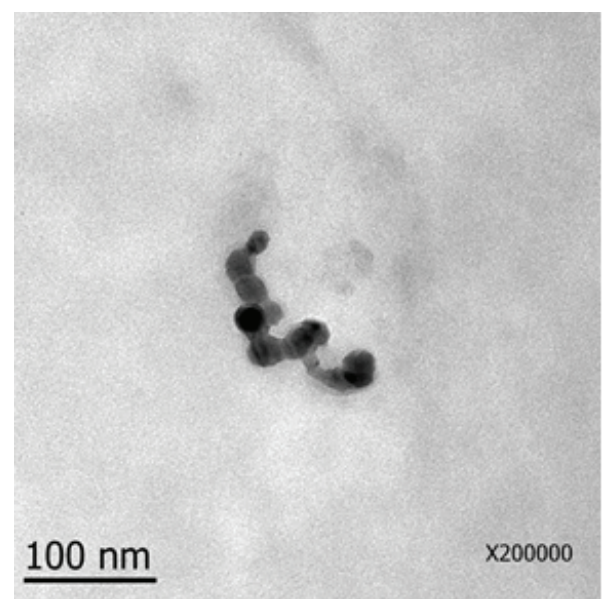

(b)

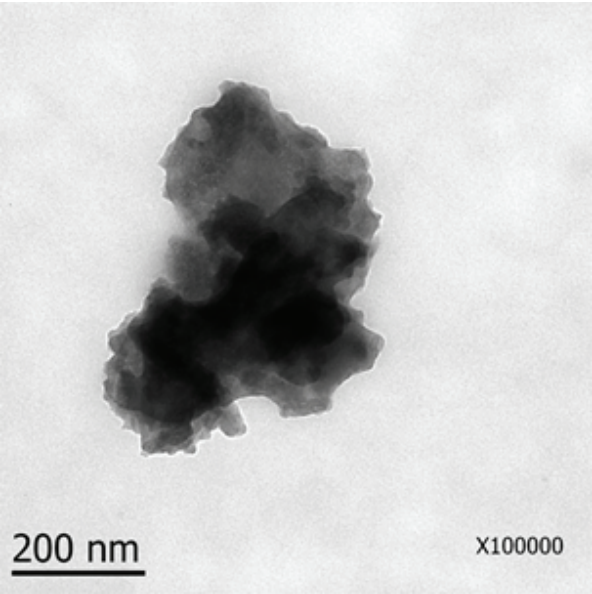

(d)

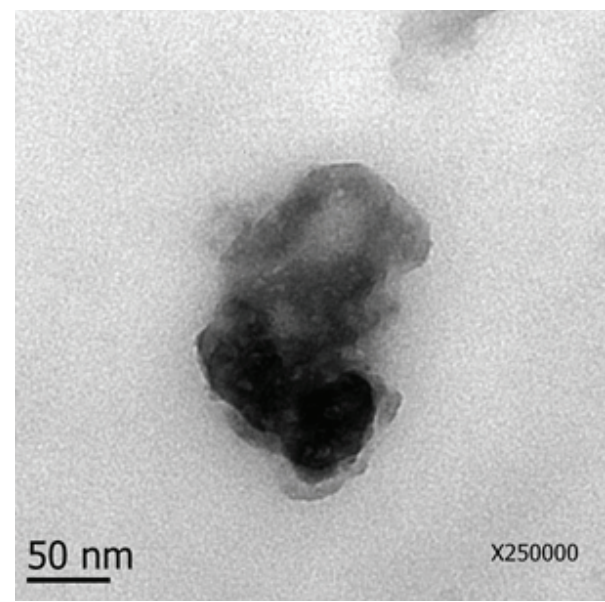

(f)

FIgURE 3: TEM images of silica particles obtained for annelids bioprocess $(a-c)$ and without bioprocess $(d-f)$.

DLS, and EDS. The particles obtained from the bioprocess contain mainly silica and $\mathrm{OH}$ groups and present a trend toward a spherical morphology; their size estimate by DLS was $530 \mathrm{~nm}$, which is smaller than those particles without the bioprocess. The bioprocess produced structural order and crystalline particles with prevailing $\alpha$-quartz phase and other silicates such as tridymite and albite. The bioprocess shows others elements in minor proportion such as aluminium, magnesium, iron, and potassium. The characteristics of these types of particles obtained from the bioprocess using 

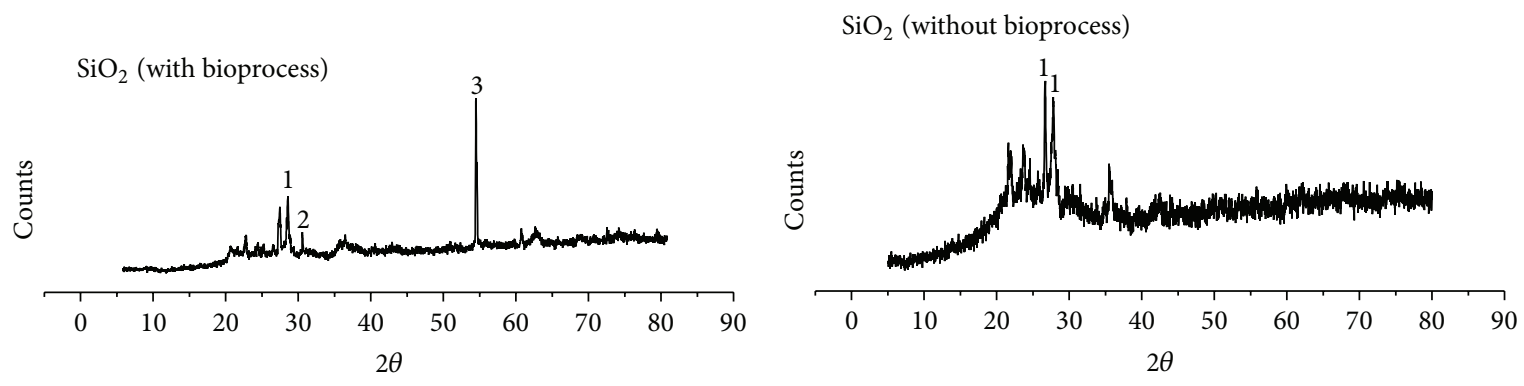

(1) Hexagonal quartz $(1,0,1)$

(2) Hexagonal tridymite (primitive) $(4,1,7)(1,1,43)$

(3) Triclinic albite $(-2,0,2)$

(a)

(b)

FIgURE 4: X-ray diffraction of silica particles obtained for annelids bioprocess (a) and without bioprocess (b).

TABLE 1: EDS to silica particles synthesized without bioprocess and with bioprocess.

\begin{tabular}{lcccc}
\hline Element & $\begin{array}{c}\text { Without bioprocess } \\
\text { \% atomic }\end{array}$ & \% weight & Element & With bioprocess \\
\% atomic
\end{tabular}

vermicompost and grass can contribute to explaining of the biological mechanism of vermicomposting specifically referred to as biomineralization. The results showed changes between the samples with and without the bioprocess. These changes are produced in the digestion process of earthworms together with the microorganisms involving separation, classification, purification, and transformation of the matter and therefore are named as biotransformation. This biological mechanism represents a novel alternative to create novel materials in a cheap and ecofriendly biostructure based manner.

\section{Conflict of Interests}

The authors declare that there is no conflict of interests regarding the publication of this paper.

\section{Acknowledgments}

The authors are grateful to Ms. Maria de Lourdes Palma for her assistance in TEM, to Dr. Genoveva Hernandez-Padron for her assistance in IR and Raman analysis, to Dr. Eric Rivera for his assistance in XRD, to Dr. Miriam Estevez Gonzalez for her assistance in DLS analysis, and also to M. T. Carrillo. Financial support from the National Council for Science and
Technology of Mexico (CONACYT) (PhD Scholarship to A. Espíndola-Gonzalez) is gratefully acknowledged.

\section{References}

[1] F. P. Massey, A. R. Ennos, and S. E. Hartley, "Silica in grasses as a defence against insect herbivores: contrasting effects on folivores and a phloem feeder," Journal of Animal Ecology, vol. 75, no. 2, pp. 595-603, 2006.

[2] P. B. Kaufman, P. Dayanandan, C. I. Franklin, and Y. Takeoka, "Structure and function of silica bodies in the epidermal system of grass shoots," Annals of Botany, vol. 55, no. 4, pp. 487-507, 1985.

[3] F. J. Ma and N. Yamaji, "Silicon uptake and accumulation in higher plants," Trends in Plant Science, vol. 11, no. 8, pp. 392397, 2006.

[4] D. W. Parry, M. J. Hodson, and A. G. Sangster, "Some recent advances in studies of silicon in higher plants [and Discussion]," Philosophical Transactions of the Royal Society B, vol. 304, no. 1121, pp. 537-549, 1984.

[5] F. M. Jian, K. Tamai, N. Yamaji et al., "A silicon transporter in rice," Nature, vol. 440, no. 7084, pp. 688-691, 2006.

[6] F. J. Ma, "Role of silicon in enhancing the resistance of plants to biotic and abiotic stresses," Soil Science and Plant Nutrition, vol. 50, no. 1, pp. 11-18, 2004. 
[7] N. Yamaji, N. Mitatni, and F. M. Jian, "A transporter regulating silicon distribution in rice shoots," Plant Cell, vol. 20, no. 5, pp. 1381-1389, 2008.

[8] J. F. Ma, N. Mitani, S. Nagao et al., "Characterization of the silicon uptake system and molecular mapping of the silicon transporter gene in rice," Plant Physiology, vol. 136, no. 2, pp. 3284-3289, 2004.

[9] K. R. Iler, The Chemistry of Silica: Solubility, Polymerization, Colloid and Surface Properties and Biochemistry of Silica, John Wiley \& Sons, Toronto, Canada, 1979.

[10] A. Espindola-Gonzalez, A. L. Martinez-Hernandez, C. Angeles, V. M. Castano, and C. Velasco-Santos, "Novel crystalline $\mathrm{SiO}_{2}$ nanoparticles via annelids bioprocessing of agro-industrial wastes," Nanoscale Research Letters, vol. 5, no. 9, pp. 1408-1417, 2010.

[11] J. D. Sauer, "Revision of Stenotaphrum (Gramineae: paniceae) with attention to its historical geography," Brittonia, vol. 24, no. 2, pp. 202-222, 1972.

[12] A. D. Genovesi, R. W. Jessup, M. C. Egelke, and B. L. Burson, "Interploid St. Augustinegrass [Stenotaphrum secundatum (Walt.) Kuntze] hybrids recovered by embryo rescue," In Vitro Cellular \& Developmental Biology —Plant, vol. 45, no. 6, pp. 659666, 2009.

[13] L. E. Datnoff, M. O. Brecht, C. M. Stiles, and B. A. Rutherford, "The role of silicon in suppressing foliar diseases in warm season turf," International Turfgrass Society Research Journal, vol. 10, pp. 175-179, 2005.

[14] S. Adhikary, "Vermicompost, the story of organic gold: a review," Agricultural Sciences, vol. 3, no. 7, pp. 905-917, 2012.

[15] C. A. Edwards and J. R. Lofty, Biology of Earthworms, Bookworm Publishing Company, Beckville, Tex, USA, 1976.

[16] E. Albanell, J. Plaixats, and T. Cabrero, "Chemical changes during vermicomposting (Eisenia fetida) of sheep manure mixed with cotton industrial wastes," Biology and Fertility of Soils, vol. 6, no. 3, pp. 266-269, 1988.

[17] J.-F. Ponge, "Humus forms in terrestrial ecosystems: a framework to biodiversity," Soil Biology and Biochemistry, vol. 35, no. 7, pp. 935-945, 2003.

[18] P. Lavelle, "Earthworm activities and the soil system," Biology and Fertility of Soils, vol. 6, no. 3, pp. 237-251, 1988.

[19] P. P. Provencio and V. J. Polyak, "Iron oxide-rich filaments: possible fossil bacteria in Lechuguilla Cave, New Mexico," Geomicrobiology Journal, vol. 18, no. 3, pp. 297-309, 2001.

[20] B. R. Frankel and A. D. Bazylinski, "Biologically induced mineralization by bacteria," Reviews in Mineralogy and Geochemistry, vol. 54, no. 1, pp. 95-114, 2003.

[21] L. Gago-Duport, M. J. I. Briones, J. B. Rodríguez, and B. Covelo, "Amorphous calcium carbonate biomineralization in the earthworm's calciferous gland: pathways to the formation of crystalline phases," Journal of Structural Biology, vol. 162, no. 3, pp. 422-435, 2008.

[22] J. Mendez, J. B. Rodriguez-González, R. Alvarez-Otero, I. M. J. Briones, and L. Gago-Duport, "Crystallization stages of the $\mathrm{CaCO}_{3}$ deposits in the earthworm's calciferous gland," in $E M C$ 2008 14th European Microscopy Congress 1-5 September 2008, Aachen, Germany, pp. 127-128, Springer, Berlin, Germany, 2008.

[23] A. C. Edwards and E. K. Fletcher, "Interactions between earthworms and microorganisms in organic-matter breakdown," Agriculture, Ecosystems \& Environment, vol. 24, no. 1-3, pp. 235$247,1988$.
[24] M. G. Gad, T. K. Semple, and M. H. Lappin-Scott, Micro-Organisms and Earth Systems, Society for General Microbiology. Symposium 65, Cambridge University Press, Cambridge, UK, 2005.

[25] J. W. Stucki, J. Wu, H. Gan, P. Komadel, and A. Banin, "Effects of iron oxidation state and organic cations on dioctahedral smectite hydration," Clays and Clay Minerals, vol. 48, no. 2, pp. 290-298, 2000.

[26] Y. Kitagawa, "Determination of allophane and amorphous inorganic matter in clay fraction of soils I. Allophane and allophane-halloysite mixture," Soil Science and Plant Nutrition, vol. 22, no. 2, pp. 137-147, 1976.

[27] M. R. Hazen, T. R. Downs, P. A. Jones, and L. Kah, "Carbon mineralogy and crystal chemistry," Reviews in Mineralogy and Geochemistry, vol. 75, no. 1, pp. 7-46, 2013.

[28] A. L. Radu, G. I. Truica, R. Penu, V. Moroeanu, and S. C. Litescu, "Use of the Fourier transform infrared spectroscopy in characterization of specific samples," UPB Scientific Bulletin B: Chemical and Materials Science, vol. 74, no. 4, pp. 137-148, 2012.

[29] C. Ascaso, L. G. Sancho, and C. Rodriguez-Pascual, "The weathering action of saxicolous lichens in maritime Antarctica," Polar Biology, vol. 11, no. 1, pp. 33-39, 1990.

[30] M. B. Caruta, Nanomaterials Researchs, Nova Science Publisher, New York, Ny, USA, 2006.

[31] B. J. Saikia, G. Parthasarathy, and N. C. Sarmah, "Spectroscopic Characterization of Olivine $\left[(\mathrm{Fe}, \mathrm{Mg})_{2} \mathrm{SiO}_{4}\right]$ in Mahadevpur $\mathrm{H} 4 / 5$ ordinary chondrite," Journal of Ameican Science, vol. 5, pp. 71-78, 2009.

[32] G. Jovanovski, P. Makreski, B. Kaitner, and B. Boev, "Silicate minerals from Macedonia. Complementary use of vibrational spectroscopy and X-ray powder diffraction for identification and detection purposes," Croatica Chemica Acta, vol. 82, no. 2, pp. 363-386, 2009. 

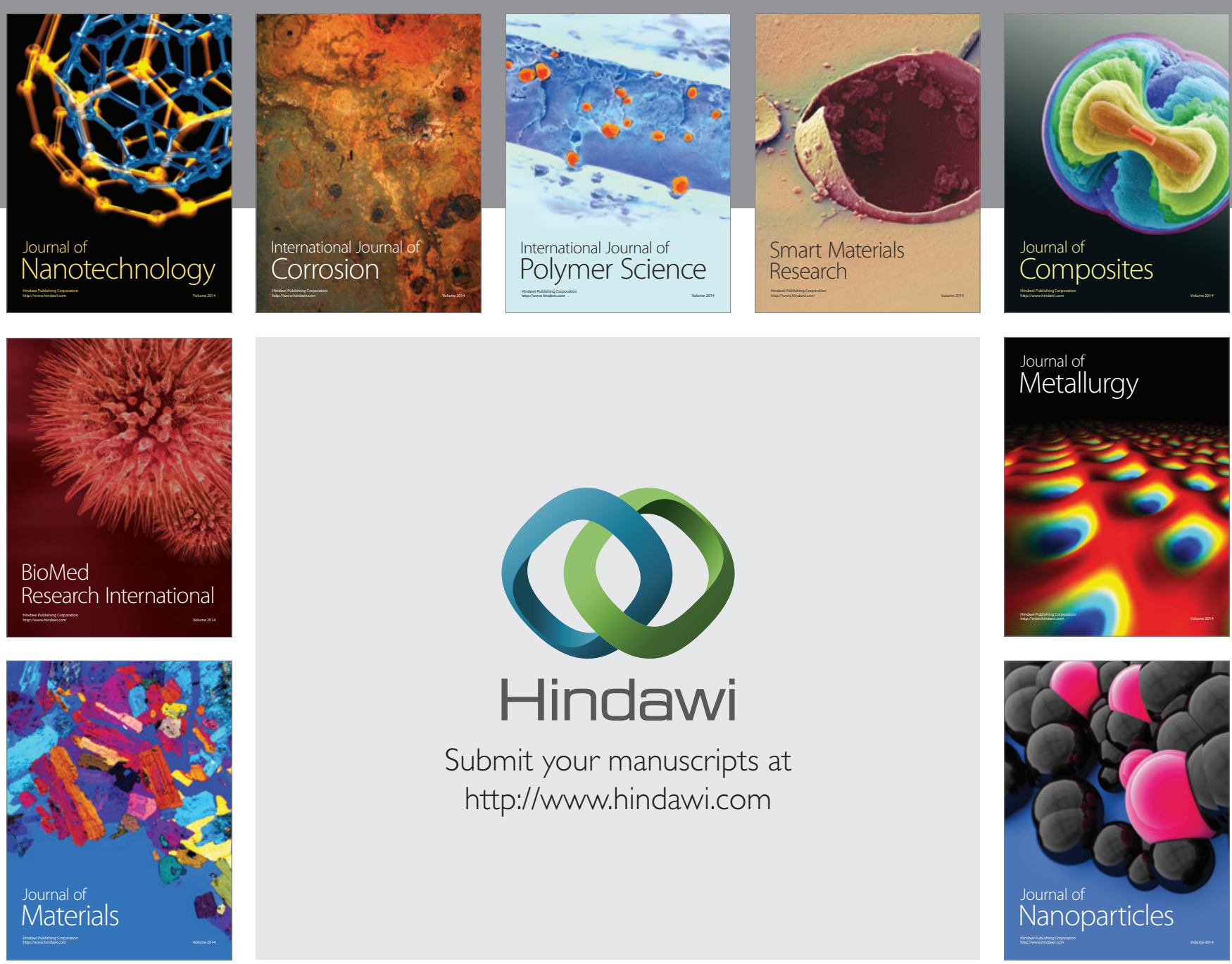

Submit your manuscripts at http://www.hindawi.com
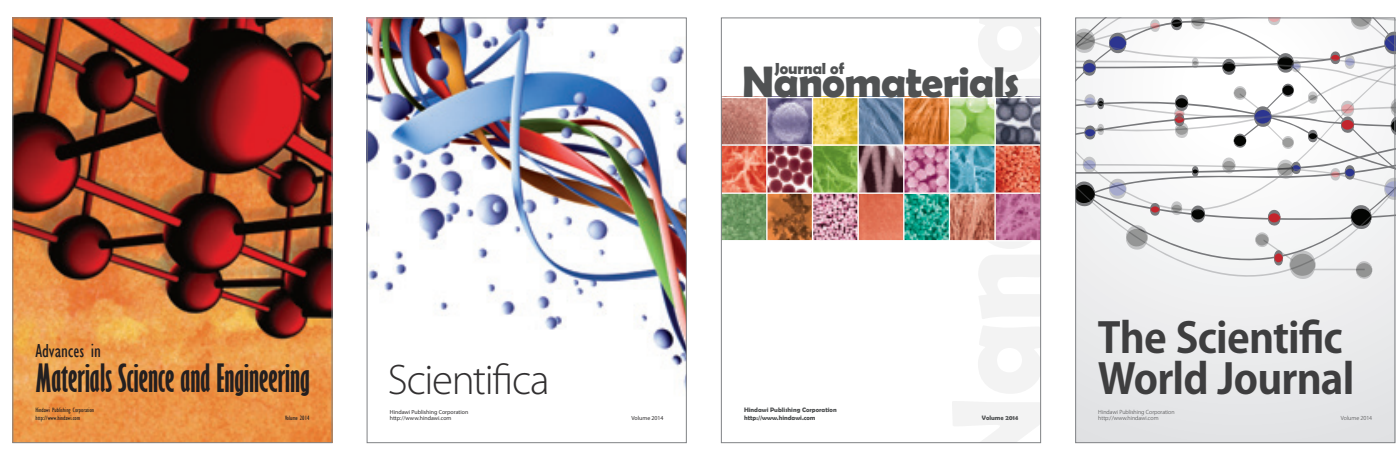

\section{The Scientific World Journal}
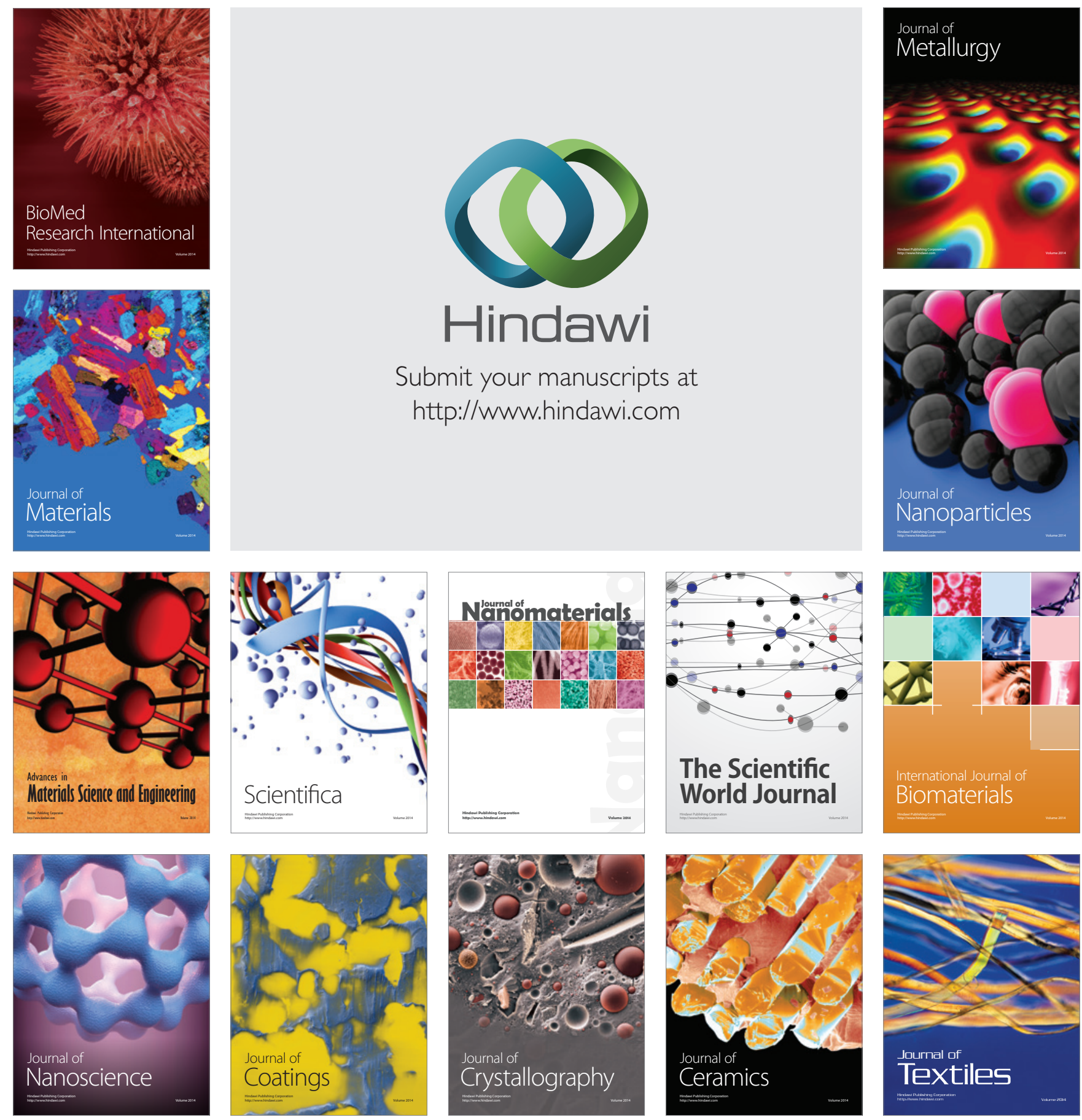